\title{
Institutional Preferences: Evidence from the Jordanian Stock Market
}

\author{
Dr. Asmaa Al-Amarneh (Corresponding author) \\ Financial and Banking Sciences Department, Private Applied Science University, Jordan \\ Po Box 166, Postal code 11931-Amman-Jordan \\ Tel: 962-795-513-798 E-mail: Asmaa.Amarneh@yahoo.com \\ Dr. Qais Al-Kilani
}

Financial and Banking Sciences Department, Private Applied Science University, Jordan

Po Box 166, Postal code 11931-Amman-Jordan

Tel: 962-795-430-102 E-mail: Qais_K@hotmail.com

Dr. Thair Kaddumi

Financial and Banking Sciences Department, Private Applied Science University, Jordan

Po Box 166 Postal code 11931-Amman-Jordan

Tel: 962-795-004-334 E-mail: Thair_lion@Asu.Edu.Jo

Received: February 14, $2011 \quad$ Accepted: March 23, $2011 \quad$ doi:10.5539/ijef.v3n5p97

\begin{abstract}
This paper provides evidence that institutional investors show preferences for large capitalization stocks, with good financial performance, high degree of leverage, low trade frequency, low annual return, and low price to book value ratio. Dividend Yield and stock volatility as measured by the standard deviations of daily prices do not seem to play an important role in institutional choice. The prudent man rule and fiduciary responsibilities of institutional managers might be good reasons to explain our findings.
\end{abstract}

Keywords: Jordanian Stock Market, Institutional ownership and preferences

\section{Introduction}

Institutional investors, as generally defined, are large investors who exercise discretion over the investments of others (Note 1). Recently, institutions account for over 43.4 percent of trading in the Jordanian stock market. Stock exchanges may be interested in institutional preference for the purpose of attracting institutional order flow, without discrimination on the type of institutions.

Part of the recent Finance literature analyzes the determinants of shareholdings by institutional stockholders. For example, Grinstein and Michaely (2005) present evidence suggesting that institutions tend to avoid stocks that do not pay dividends. Among stocks that pay dividends, institutions tend to hold more of those that pay lower dividends. Institutions also prefer firms that repurchase more stock.

The literature on institutional preferences has used price per share, share turnover, and firm size as proxies for liquidity (see, for example, Bennett et al. (2003), Gompers and Metrick (2001), Del Guercio (1996), and Falkenstein (1996)) and found that they affect institutional holdings.

This paper investigated empirically the firm specific variables, which influence the investment decision of institutional investors. The share holding of the institutions is taken in percentage form to control the firm size. The relationship is observed through the correlation and regression coefficients.

The rest of the paper proceeds as follows: section 2 presents literature review, section 3 contains a discussion of the hypotheses, section 4 discusses the methodology and variables, section 5 reviews results, section 6 concludes the paper.

\section{Literature Review}

As the Jordanian equity market is growing, the trend and future prospects in domestic and foreign institutional investments has become a topic of great concern. The combination of institutions' better monitoring and information gathering abilities and the advantages some forms of payouts offer institutions (taxes, prudent man rule (Note 2)) have led some researchers to investigate the preferences of institutions when making investment decisions.

Elyas et al, (2010) investigate the association between corporate firm performance and the level and stability of 
institutional ownership within a simultaneous equation model. Their main ownership stability measures include ownership persistence and the time-lengths over which investors hold non-zero shares or maintain their shareholding. They find that there is a positive relationship between firm performance and institutional ownership stability, accounting for the shareholding proportion. This relationship is robust to the employment of ownership turnover measures used in the literature and consistent with the view that stable institutional investors play an effective role in monitoring.

Rubin and Smith (2009) found that the sign of the correlation between institutional ownership and volatility depends on the firm's dividend policy: institutional ownership is negatively (positively) related to volatility among non-dividend (dividend) paying stocks. The empirical results are consistent with an interaction between institutional preference for low volatility and the tendency of higher levels of institutional ownership to increase volatility through their trading behavior. This result is robust to many control variables and possible endogeneity concerns. Supporting their conjecture that institutions herd on dividend signals they found that the correlation between turnover and institutional ownership is higher for dividend paying stocks, and that the positive correlation between turnover and institutional ownership is higher on dividend declaration days. Finally, they found that the level of institutional ownership drops following an increase in volatility for both dividend payers and non-payers, and that volatility rises following increased institutional ownership for dividend paying stocks.

Rakotomaves (2009) provides evidence that suggests that institutions prefer stocks that have low effective spread, low price impact, large average trade size, low trade frequency and low volatility. Depth does not seem to play an incremental role in institutional choice. Overall, the results point to the possibility that institutions attempt to minimize the costs of stealth trading. These findings still hold when the period under study (1998-2004) is divided into various sub periods, and also when the explanatory variables are de- trended. An extensive set of control variables was used.

Yuan et al. (2008) test empirically the impact of mutual funds' ownership on firm performance in China, using a large sample for the period of 2001-2005. They find that equity ownership by mutual funds has a positive effect on firm performance (measured by Tobin's Q). The result is robust to several measures of firm performance and various estimations. Their finding supports recent regulatory efforts in China to promote mutual funds as a corporate governance mechanism and suggests that pooling diffuse minority interests of individual shareholders who are prone to free-rider problems via mutual funds is beneficial.

Cai and Zheng (2004) explore the dynamics of the relation between institutional trading and stock returns. They find that stock returns Granger-cause institutional trading (especially purchases) on a quarterly basis. The robust and significant causality from equity returns to institutional trading can be largely explained by the time-series variation of market returns, that is, institutions buy more popular stocks after market rises. Stock returns appear to be negatively related to lagged institutional trading. A further analysis of the behavior of trading and the returns of the traded stocks reveals evidence that stock with heavy institutional buying (selling) experience positive (negative) excess returns over the previous 12 months.

Faugere and Shawky (2003) investigate the differences in the holdings of institutional investors relative to individual investors during an eight-month period between March and November 2000, where the Nasdaq Composite index fell $46.23 \%$ in value. We find evidence that during that market decline, institutional investors held stocks with less return volatility than individual investors. Our evidence of institutional investor preference for holding lower volatility stocks in a declining market may indicate their relatively greater sensitivity to downside risk. As a consequence, institutional investors are found to perform better than individual investors during that specific time period.

Woidtke (2002) in his paper examines the valuation effects associated with the incentive structures of different types of institutional investors using the ownership levels of public and private pension funds in a firm. The results suggest that institutional monitoring is associated with valuation effects when both observable and unobservable aspects of the relationship between institutions and firms are taken into account. Moreover, the valuation effects vary according to the objective functions of institutions' administrators. Thus, other shareholders do not necessarily benefit from relationships between institutions and managers, and they could be hurt when the institutional agents watching firm agents have conflicts of interest with other shareholders.

Gompers and Metrick (2001) analyze institutional investors' demand for stock characteristics and the implications of this demand for stock prices and returns. They find that institutional investors compared to individual investors prefer stocks in larger market capitalization companies and that are more liquid and have higher book-to-market ratios. They do not, however, detect any significant relation between institutional holdings and stock return volatility. 
Chakravarty (2001) shows that institutional trades may impact stock prices because of superior information.

Sias (1996) argues that institutional investors are likely to choose less volatile stocks for several reasons: 1) many institutions are governed by the prudent man rule; 2) greater institutional interest may imply more and better information; and 3) institutional investor behavior is less susceptible to fads or noise trading influences.

This paper contributes to the literature in the following ways. First, it investigated empirically the firm and stock specific variables, which influence the investment decision of institutional investors. Second, it covers a more recent period, 2005-2009. Third, it provides valuable information about institutional holdings preferences which can be used by individual investors when making decisions about their investments.

\section{Hypotheses Development.}

Institutional supporters argue that institutional investors enhance corporate efficiency in two ways. First, institutional investors perform quality research in order to identify efficient firms for investing funds, thus directing scarce capital to its most efficient use. Second, according to institutional supporters, large institutional stakes in public corporations provide strong economic incentives for institutional investors to monitor managers. This institutional monitoring enhances managerial efficiency and the quality of corporate decision making. Also, Institutions may be informed traders. The hypothesis suggests that institutions have superior information about dividend increases and use that information to trade long before the increases are announced. If institutions are better informed than other investors, profit maximization dictates that they choose stocks with greater asymmetric information-based expected profit, ceteris paribus. Moreover, since the majority of institutions are subject to either some prudent-man rules and/or have a relative tax advantage for dividends, they have to invest a larger proportion of their holdings in "prudent" stocks.

In this paper we are interested in learning whether the relationship between institutional ownership and corporate and stock performance in the Jordanian stock market is important or not. The following hypotheses will be empirically tested using OLS regression.

Hypothesis 1: corporate performance has a positive effect on institutional holdings.

Hypothesis 2: stock performance has a positive effect on institutional holdings.

\section{Methodology}

\subsection{Sample selection and sources of data.}

The sample includes annual observations of publicly owned firms, chosen from the pool of companies listed in ASE that satisfied each of the following criteria: (a) Financial service firms are excluded because of their special asset composition, high leverage, and the fact that, due to the uniqueness of this industry, the ROE and other performance measures for these firms cannot be meaningfully compared to those of the firms in the other industries, (b) the firm's common-stock shares must have been listed without interruption on the ASE between 2005 and 2009, and (c) all financial data are fully available. The data used to compute the firm performance and stock performance measures and control variables are drawn from ASE company guides and publications, while Institutional ownership data are from Jordanian securities Depository Center (SDC).

\subsection{Model and variables}

\subsubsection{Variables}

In this paper firm specific characteristics (financial performance and stock performance) have been analyzed. The relationship between these attributes and institutional investment has been examined.

Dependent Variable: Institutional Holdings: are the percentages of shares outstanding held by funds and institutions.

\section{Independent Variables: Corporate and stock performance.}

Corporate performance: Prior research observed that more funds were invested in firms with large market capitalization, higher dividend yield, higher leverage, and higher Tobin's Q, (ROE, ROA, EPS). The measures of performance considered in the previous research studies have guided the selection of the ratios in our study.

Stock performance: Stock market performance indicates the institutional investor's perceptions about the company. Over $80 \%$ of the reporting parameters used to manage the company are designed to gauge returns to shareholders (Prasanna, 2008). Most management decisions are therefore biased towards delivering short-term value to them. An income statement or balance sheet does not reveal the company's ability to create value for customers, employees or shareholders. Figures contained in the financial reports fail to capture fully the 'essence' of firm operations. This fact is particularity evident in the case of companies whose book value is markedly different from the market value. The book value of the equity measures approximately the capital contributed by the shareholders, where as market price 
of the equity reflects how productively the firm has employed the capital contributed by the shareholders as assessed by stock market. The ratio of price to book value (P/B) gauges whether the market valuation of the company is relative its worth or not. Market prices reflect not only the performance but also investor's expectations about the future performance. Also market return has been computed to measure the shareholders returns. It is computed based on share price appreciation to reflect the return to the shareholders. All these ratios are computed annually. Finally, Stock turnover used as a proxy for stock liquidity.

\section{Control Variables:}

Market capitalization used as proxy for firm size, and industry dummy variable which take a value of 1 for financial sector, 2 for service sector and 3 for industry sector.

\subsubsection{Model}

The hypothesis to be tested is that firm institutional holdings are affected by the corporate performance factors and the stock market factors. However, the results will be difficult to interpret when there is a problem of endogeneity. Institutional ownership can enhance firm performance but good performance may also attract the investors and/or encourage them to hold onto the stock over a longer horizon demonstrating ownership stability. To account for endogeneity between performance and institutional ownership by: first, we regress the contemporaneous performance measures on the one-period lag values of institutional ownership and other explanatory variables. The lag allows for the effect of change in sample firms' ownership to show up in future firm performance. A similar approach is also used in Hermalin and Weisbach (1991), Helwege and Liang (1996) and Coles et al. (2006). Second, we include firm-specific fixed-effects to control for the possibility that endogeneity arises from omitted unobserved factors (e.g., management expertise) that may be correlated with both institutional ownership and firm corporate performance measures (Himmelberg et al., 1999).

Our methodology is specifically designed to control for three econometric issues: (1) the presence of unobserved firm-specific effects (which are eliminated by taking first differences of the variables);(2) the autoregressive behavior of institutional holdings; and (3) likely endogeneity of the explanatory variables. In particular, we test the following models:

$$
\text { InstitutionalHoldingsi, } t=\alpha 1+\text { CorporatePerformance }, t-1+\text { SInstitutionalHoldings, } t-1+C_{i, t}-1+\mathcal{E}_{i t}
$$

$\mathrm{Eq}$

InstitutionalHolding $s i, t=\alpha 1+$ StockPerformance $i, t-1+$ InstitutionalHolding $s i, t-1+C_{i, t}-1+\varepsilon_{i t}$

Where $\alpha_{\mathrm{i}}$ represents regression coefficient and $\varepsilon$ is an error term; and $\mathrm{C}_{\mathrm{it} \_1}$ contains control variables (Size and industry dummies). The first equation will be used to test the first hypothesis, and equation two will be used to test the second one.

\section{Data Description and Empirical Results.}

The summary statistics as given in Table (1) show that around $44 \%$ of the capital comes from institutional investors on an average among ASE companies. The financial performance for the selected companies was not good; since $22 \%$ of the ROE observation was negative. The selected companies highly depend on debt, about $41.3 \%$ of its financing come from others money. Also, the statistics show that the mean of dividend yield was $0.081 \%$, with a maximum value of $4 \%$, and about $58.57 \%$ of the observation was zero in value. The average annual rate of return was $6.7 \%$ with $60 \%$ of the observation was negative. The mean for price volatility was $58.2 \%$ and about $94.7 \%$ of the risk level observations were less than $200 \%$, within this group of stocks the institutions holdings on average was $44 \%$.

Insert Table $<$ table $1>$

The first hypothesis to be tested is that the institutional ownership is a function of corporate performance and other control variables. After employing OLS regressions, table (2) presents the relationship between institutional holdings and the corporate performance. The results confirm that among the various corporate performance variables ROE ratio, leverage, and market capitalization have a significant effect on institutional ownership. Which indicates that institutional investor prefer companies with higher financial performance (high ROE), higher degree of leverage, and large in size without considering the industry sector. The negative insignificant relationship between institutional ownership and dividend yield indicate that institutional investor does not prefer dividend distribution policy, the insignificancy is a result of that, most of selected companies did not pay dividend during the study period. About $58.57 \%$ of the observations were zero, and the mean of institutional holding for these companies was $43.9 \%$, which indicate that institutions avoid firms that pay dividends.

Insert Table $<$ table $2>$ 
We apply the OLS regressions again to test the relationship between institutional holdings and the stock performance in the market. The results given in Table 3 confirm that institutional investors prefer low priced stocks, low liquidity (stock turnover), with high market rate of return that will be highly valued by investors (high P/B). They are not interested in the trading value or the risk level and the industrial sector the firm belong to.

Insert Table $<$ table3 $>$

\section{Conclusions}

This paper empirically observed that the institutional investment is more in companies with higher market capitalization. Among corporate performance variables the leverage and financial performance are more influencing variables on their investment decision regardless of industry sector. Also the study provides a pointer for the stock performance in the ASE is the strong basis for attracting more institutional investment for the individual companies. The institutional investors will increase their holdings when the stock prices and turnover decreased. At the same time, good stock valuation from investors (high $\mathrm{P} / \mathrm{B}$ ratio) attracts the institutional ownership holdings.

\section{References}

Bennett, J. A., Sias, R. W., and L. T. Starks. (2003).Greener Pastures and the Impact of Dynamic Institutional Preferences. Review of Financial Studies, 16, 1203-1238, doi:10.1093/rfs/hhg040, http://dx.doi.org/10.1093/rfs/hhg040.

Cai, Fang and Lu Zheng. (2004). Institutional Tradind and Stock Return. Finance Research Letters, 1(3), 178-189, doi:10.1016/j.frl.2004.06.003, http://dx.doi.org/10.1016/j.frl.2004.06.003

Chakravarty, Sugato. (2001), "Stealth Trading: Which Traders' Trades Move Prices.? Journal of Financial Economics.61,289-307, doi:10.1016/S0304-405X(01)00063-0, http://dx.doi.org/10.1016/S0304-405X(01)00063-0

Coles, J.L., Daniel, N.D., Naveen, L. (2006).Managerial incentives and risk-taking. Journal of Financial Economics.79, 431-468, doi:10.1016/j.jfineco.2004.09.004, http://dx.doi.org/10.1016/j.jfineco.2004.09.004

Del Guercio, D. (1996). 'The Distorting Effect of the Prudent-Man Laws on Institutional Equity Investmet. Journal of Financial Economics, 40, 31-62, doi:10.1016/0304-405X(95)00841-2, http://dx.doi.org/10.1016/0304-405X(95)00841-2

Elyasiani ,Elyas and Jingyi Jia.(2010).Distribution of institutional ownership and corporate firm performance. Journal of Banking \& Finance, 34, 606-620, doi:10.1016/j.jbankfin.2009.08.018, http://dx.doi.org/10.1016/j.jbankfin.2009.08.01 .

Falkenstein, E.(1996).Preferences for Stock Characteristics as Revealed by Mutual Fund Portfolio Holdings. Journal of Finance, 51, 111-135, doi:10.2307/2329304, http://dx.doi.org/10.2307/2329304

Faugere, Chreistopher and Hany Shawky.(2003).Institutional holdings and volatility. Working paper, Center of Institutional Investment Management, University of Albany.

Gompers, Paul and Andrew Metrick.(2001).Institutional Investors and equity Prices. The Quarterly Journal of Economics, Feb. (2001).

Grinsten, Yaniv and Roni Michaely.(2005).Institutional Holdings and Payout Policy. The Journal of Finance. Lx(3), pp1389-1426.

Helwege, J., Liang, N. (1996). Is there a pecking order? Evidence from a panel of IPO firms. Journal of Financial Economics, 40, 429-458, doi:10.1016/0304-405X(95)00851-5, http://dx.doi.org/10.1016/0304-405X(95)00851-5

Hermalin, B., Weisbach, M. (1991). The effects of board composition and direct incentive on firm performance. Financial Management, 20, 101-112, doi:10.2307/3665716, http://dx.doi.org/10.2307/3665716

Himmelberg, C.P., Hubbard, G.R., Palia, D. (1999). Understanding the determinants of managerial ownership and the link between ownership and performance. Journal of Financial Economics, 53, 353-384, doi:10.1016/S0304-405X(99)00025-2, http://dx.doi.org/10.1016/S0304-405X(99)00025-2

Prasanna, P. K. (2008). Foreign Institutional Investors: Investment Preferences in India, JOAAG, 3(2), 40-51.

Rakotomavo , Michel.(2009). Microstructure and Institutional Holdings. Journal of Money, Investment and Banking, ISSN 1450-288X Issue 7I.

Rubin, Amir and Daniel R. Smith.(2009).Institutional ownership, volatility and dividends. Journal of Banking \& Finance, 33, 627-639, doi:10.1016/j.jbankfin.2008.11.008, http://dx.doi.org/10.1016/j.jbankfin.2008.11.008

Sias, R.(1996),Volatility and the Institutional Investor. Financial Analysts Journal, 52, 13-20, 
doi:10.2469/faj.v52.n2.1976, http://dx.doi.org/10.2469/faj.v52.n2.1976

Woidtke, T.(2002).Agents Watching Agents: Evidence from Pension fund Onership and Firm Value. Journal of Financial Economics, 63 (1), doi:10.1016/S0304-405X(01)00091-5, http://dx.doi.org/10.1016/S0304-405X(01)00091-5.

Yuan, Rongli, Jason Zezhong Xiao and Hong Zou.(2008).Mutual funds' ownership and firm performance: Evidence from China. Journal of Banking \& Finance, 32 , 1552-1565, doi:10.1016/j.jbankfin.2007.08.001, http://dx.doi.org/10.1016/j.jbankfin.2007.08.001 .

\section{Notes}

Note 1. ASE define mutual fund as an established investment fund whereby an investment company pools funds from investors in order to purchase a wide variety of financial instruments that will meet the fund's investment goals.

Note 2. unlike most individual investors, institutions are fiduciaries. They invest on behalf of others and are, therefore, subject to agency conflicts. As a result, they are constrained by several rules aimed at preventing them from speculating with other peoples' money. For example, those institutions governed by "prudent-man" rules invest a larger proportion of their holdings in "prudent" stocks.

Table 1. Descriptive Statistics.

\begin{tabular}{|l|l|l|l|l|}
\hline Variables & Minimum & Maximum & Mean & Std. Deviation \\
\hline Institutional Holdings & 0.0035 & 99.117 & 44.032 & 24.548 \\
\hline Inst.Holdings(\%) & \multicolumn{5}{l|}{} \\
\hline Corporate performance Variables & -145.040 & 2534.56 & 14.500 & 104.398 \\
\hline ROE(\%) & 0.648 & 11142.8 & 160.342 & 800.472 \\
\hline Size (million JD) & 0.27 & 641.08 & 41.314 & 33.963 \\
\hline Leverage(\%) & 0 & 986 & 58.2 & 88.7 \\
\hline Risk(\%) & 0 & 4 & 8.08 & 0.217 \\
\hline Div.Yield(\%) & \multicolumn{3}{|l|}{} \\
\hline Stock Performance variables & -6.667 & 7.692 & 1.855 & 1.2 \\
\hline P/B & 447 & $3,350,289,234$ & $70,081,622$ & $24,343,262$ \\
\hline Trading Volume(JD) & 63.3 & 3.6 & 4.655 \\
\hline Avg.Price(JD) & 0.26 & 47473 & 185.148 & 1807.037 \\
\hline Share Turnover & 0.01 & 565.714 & 6.724 & 64.299 \\
\hline Market return (\%) & -82.456 & & \\
\hline
\end{tabular}

Table 2. Panel Data Regression (Random effect): institutional holdings and corporate performance.

\begin{tabular}{|l|l|l|l|}
\hline \multicolumn{1}{|l|}{ InstitutionalHoldingsi, $t=\alpha 1+$ CorporatePerformance, $t-1+$ SInstitutionalHoldings, $t-1+C_{i, t}-1+$ Eit } \\
\hline & coefficient & t-statistic & Prob (t.statistic) \\
\hline ROE(-1) & 0.00592 & 1.749584 & $0.0807 *$ \\
\hline Leverage(-1) & 0.031477 & 2.689633 & 0.0074 \\
\hline Div. Yield(-1) & -0.012462 & -0.694726 & 0.4875 \\
\hline Log Cap. & 0.746494 & 2.378466 & 0.0177 \\
\hline Industry & 0.562823 & 0.590586 & 0.5550 \\
\hline HoldingsPecent(-1) & 0.867429 & 48.99123 & 0.0000 \\
\hline Constant C & -6.910214 & -1.29763 & 0.1970 \\
\hline Adj. R-square & 0.742803 & & \\
\hline D.W & 1.989343 & & \\
\hline F.statistic & 180.3809 & \\
\hline Prob(F.stat) & 0.0000 & \\
\hline
\end{tabular}

\footnotetext{
${ }^{*}$ Value is significant at $10 \%$.
} 
Table 3. Panel Data Regression (Random effect): institutional holdings and stock performance

\begin{tabular}{|c|c|c|c|}
\hline Institutio nalHolding & Si,t $=\alpha 1+$ StockPerfo $\quad$ rmance $i, t-1+$ Institutio & nalHolding & $-C_{i, t}-1+\varepsilon i t$ \\
\hline Variables & Coefficient & t-statistic & Prob (t.statistic) \\
\hline Average price & -0399182 & -2.520022 & 0.0120 \\
\hline Log Cap. & 1.081261 & 2.750697 & 0.0061 \\
\hline P/B Ratio(-1) & 1.052592 & 2.358723 & 0.0187 \\
\hline Share Turnover & -0.000322 & -1.724669 & $0.0851^{*}$ \\
\hline Log Value Traded & -0.001905 & -0.009361 & 0.9925 \\
\hline Market rate of return(-1) & 0.010289 & 1.723389 & $0.0854 *$ \\
\hline Total risk & 0.331209 & 0.795329 & 0.4268 \\
\hline Industrial sector & 0.592831 & 0.611086 & 0.5414 \\
\hline HoldingsPecent(-1) & 0.85727 & 48.58402 & 0.0000 \\
\hline Constant C & -13.87356 & -1.975943 & 0.0487 \\
\hline Adj. R-square & 0.738204 & & \\
\hline D.W & 1.985624 & & \\
\hline F.statistic & 176.1391 & & \\
\hline Prob(F.stat) & 0.0000 & & \\
\hline
\end{tabular}

*Values are significant at $10 \%$ level 